\title{
Endothelial-Derived Endothelin-1 Promotes Pulmonary Vascular Remodeling in Bleomycin-Induced Pulmonary Fibrosis
}

\author{
A. B. HARTOPO ${ }^{1,2}$, N. ARFIAN ${ }^{1,3}$, K. NAKAYAMA ${ }^{1}$, Y. SUZUKI ${ }^{1,4}$, K. YAGI $^{4}$, N. EMOTO ${ }^{1,4}$ \\ ${ }^{1}$ Division of Cardiovascular Medicine, Department of Internal Medicine, Kobe University Graduate \\ School of Medicine, Kobe, Japan, ${ }^{2}$ Department of Cardiology and Vascular Medicine, Faculty of \\ Medicine, Public Health and Nursing, Universitas Gadjah Mada, Yogyakarta, Indonesia, \\ ${ }^{3}$ Department of Anatomy, Faculty of Medicine, Public Health and Nursing, Universitas Gadjah \\ Mada, Yogyakarta, Indonesia, ${ }^{4}$ Department of Clinical Pharmacy, Kobe Pharmaceutical University, \\ Kobe, Japan
}

Received November 20, 2017

Accepted May 15, 2018

\section{Summary}

Endothelin-1 (ET-1) induces pulmonary vascular remodeling and pulmonary hypertension secondary to pulmonary fibrosis. Given that endothelial cells are the main source of ET-1 and ET- 1 from other cells may encounter difficulty penetrating vascular compartments, we hypothesize that endothelial-derived ET-1 promotes vascular remodeling secondary to pulmonary fibrosis. We used vascular endothelial ET-1 knock-out (VEETKO) and Wild type mice for this research. They were given intratracheal bleomycin and euthanized at day 28. We quantified pulmonary fibrosis, measured lung ET-1 and its receptors' expression, and assessed pulmonary vascular remodeling by calculating medial wall index, muscularization index, adventitial collagen and adventitial fibroblast and macrophage accumulation. Right ventricle remodeling was also assessed. Both VEETKO and Wild type mice developed comparable pulmonary fibrosis and similar fibrosis-related gene expression. Compared to Wild type mice, bleomycin-induced VEETKO mice had lower ET-1 peptide levels $(15.4 \mathrm{pg} / \mathrm{mg}$ vs. $31.2 \mathrm{pg} / \mathrm{mg}, \mathrm{p}<0.01)$. Expression of both ET-1 receptors mRNAs were increased in fibrosis models. Bleomycin-induced fibrosis VEETKO mice had significantly less muscularized arterioles, lower muscularization index and attenuated adventitial collagen, fibroblast and macrophage accumulation as compared to that of Wild type mice. Right ventricular pressure, hypertrophy and fibrosis did not increase both in VEETKO and Wild type mice despite the more enhanced vascular remodeling in Wild type. In conclusion, endothelialderived endothelin-1 promotes pulmonary vascular remodeling secondary to bleomycin-induced pulmonary fibrosis.

\section{Key words}

Endothelial endothelin-1 • Pulmonary hypertension • Pulmonary fibrosis • Vascular remodeling

\section{Corresponding author}

N. Emoto, Division of Cardiovascular Medicine, Department of Internal Medicine, Kobe University Graduate School of Medicine, Kobe, Japan. E-mail: emoto@med.kobe-u.ac.jp

\section{Introduction}

Secondary pulmonary arterial hypertension is a terminal state of interstitial lung disease with a prevalence between 20-40\% (Behr and Ryu 2008). In interstitial lung diseases, such as connective tissue disease, sarcoidosis and idiopathic pulmonary fibrosis, continual fibrotic remodeling is a common final pathway which leads to destroyed lung anatomic organization (Strieter and Mehrad 2009). In addition to fibrotic remodeling in the tissue, pulmonary vascular vessels also undergo remodeling such as vasoconstriction, endothelial proliferation and apoptosis, wall thickening and muscularization, perivascular fibrosis and vessel loss, all of which is thought to provoke pulmonary hypertension (Farkas et al. 2011).

Several mediators have been identified in promoting pulmonary vascular remodeling and pulmonary hypertension due to interstitial lung disease, one of which is endothelin-1 (ET-1) (Behr and Ryu 2008, Farkas et al. 2011). The lungs are a plentiful source of 
ET-1 which is detected in endothelial cells, bronchial and alveolar epithelial cells and alveolar macrophages (Giaid et al. 1991, Guembe and Villaro 2001, Park et al. 1997). Increased ET-1 is documented in pulmonary fibrosis and involved in the ensuing vascular remodeling (Park et al. 1997, Giaid et al. 1993). In addition to inducing vasoconstriction, ET-1 also promotes extracellular matrix production (Rodriguez-Vita et al. 2005), vascular smooth muscle cell proliferation and migration (Komuro et al. 1988, Meoli and White 2010) as well as fibroblast collagen production (Shi-Wen et al. 2001). All of these properties enable ET-1 to promote vascular remodeling in pulmonary fibrosis.

In fibrotic lung disease, vascular remodeling occurs in all of the layers of vascular compartments: intima, media and adventitia (Farkas et al. 2011, Nathan et al. 2007). Both heterogeneous location and fibrosis severity affect the scale of vascular remodeling, either locally or globally (Nathan et al. 2007). Promotion of vascular remodeling by ET-1 in pulmonary fibrosis may depend on the source of ET-1 (Farkas et al. 2011). Given that endothelial cells are the main source of ET-1 and ET-1 from other cells, such as lung epithelial cells and macrophages, may encounter difficulty penetrating vascular compartments, we hypothesize that endothelialderived ET-1 contribute substantially in promoting vascular remodeling secondary to pulmonary fibrosis.

Accordingly, the aim of this study is to investigate the role of endothelial-derived ET-1 in promoting pulmonary vascular remodeling secondary to pulmonary fibrosis. For this purpose, we used mice lacking endothelial-derived ET-1 which were subjected to intratracheal bleomycin instillation to generate pulmonary fibrosis.

\section{Material and Methods}

Vascular endothelial ET-1 knock-out (VEETKO) mice generation

For this study, we used 8- to 10-week-old ET-1 ${ }^{\text {floxflox; }}$ Tie2-Cre $(+)$ mice (dubbed vascular endothelial ET-1 knock-out (VEETKO) mice) and their Wild-type littermates (ET- $1^{\text {flox/flox; }}$ Tie2-Cre (-)) as controls. The details of generation and characterization of VEETKO mice have been previously reported (Kisanuki et al. 2010). In brief, ET- $1^{\text {flox/flox }}$ mice were bred with Tie2Cre transgenic mice to obtain ET- $1^{\text {flox/flox }}$; Tie2-Cre $(+)$ mice, which were born without developmental deformation and were apparently healthy into adulthood (Kisanuki et al. 2010). These mice and their littermates were maintained in our experimental animal facility. The procedures of experiments were in accordance with the Guidelines for Animal Experiments of Kobe University Graduate School of Medicine, Kobe, Japan.

\section{Bleomycin intratracheal instillation}

Mice were anesthetized with intraperitoneal pentobarbital (Kyoritsu-Seiyaku, Tokyo, Japan), placed supinely on surgical board and operated to expose the trachea. The surgical board was raised to form a 40 degree angle with mice head at the top; a $26 \mathrm{G}$ needle was used to penetrate the trachea into the airway and $10 \mu \mathrm{g} / \mathrm{g}$ body weight (50-60 $\mu$ ) of bleomycin (Jena Bioscience, Jena, Germany) was given to the fibrosis mice. Equal volume of normal saline vehicle was given to control mice in similar procedures. Neck incision was closed and mice were observed until well recovered. Mice were maintained and finally euthanized at 28 days after bleomycin or saline instillation.

\section{Pulmonary collagen quantification}

Right pulmonary lobes were snap-frozen in liquid nitrogen. Whole right lobes (superior, middle and inferior lobes) were thawed and weighed. They were minced and mixed into one microtube for collagen quantification. Minced sample was washed in cold phosphate buffered saline and mixed with $0.5 \mathrm{M}$ acetic acid and pepsin for collagen extraction. The clarified extract was recovered and $1.0 \mathrm{ml}$ sample was mixed with acid neutralizing reagent into $1.5 \mathrm{ml}$ conical microcentrifuge tube. Cold collagen isolation and concentration reagent was added into tube, mixed with tube inversion and incubated overnight at $4{ }^{\circ} \mathrm{C}$. Subsequently, tube was centrifuged at $12,000 \mathrm{rpm}$ for $10 \mathrm{~min}$. The transparent pellet was collected by removing $1 \mathrm{ml}$ supernatant with micropipette from the tube. For collagen quantification assay, Sircol Dye Reagent $(1.0 \mathrm{ml})$ was added and mixed evenly by gentle mechanical shaker for $30 \mathrm{~min}$. The sample was centrifuged at $12,000 \mathrm{rpm}$ for $10 \mathrm{~min}$ and the tube was gently inverted and drained. To remove unbound dye from the surface of the pellet and the inside of the tube, acid-salt wash reagent was added, centrifuged at $12,000 \mathrm{rpm}$ for $10 \mathrm{~min}$ and drained with the supernatant. To release the collagen bound dye into solution, alkali reagent was added into tube and mixed with vortex for $5 \mathrm{~min}$. A $200 \mu \mathrm{l}$ sample was transferred into individual well of 96 microwell plate and $555 \mathrm{~nm}$ absorbent was measured by plate reader. Collagen concentration was set up by standard curve. The 
pulmonary collagen measurements were performed with Sircol collagen assay, a quantitative dye-binding method designed for the analysis of acid and pepsin-soluble collagens, in accordance with manufacturer protocol. The sensitivity of assay is $1.0 \mu \mathrm{g} / 100 \mu \mathrm{l}$. It measures mammalian collagens, types $\mathrm{I}$ to $\mathrm{V}$ (Biocolor, Carrickfergus, UK).

\section{Pulmonary histology examination}

Mice were anesthetized with intraperitoneal pentobarbital (Kyoritsu-Seiyaku, Tokyo, Japan) and the thorax was opened. Right pulmonary lobes were collected and snap-frozen while the right hilus was tightly sutured. A $20 \mathrm{G}$ angiocath was inserted and fixed into the trachea, then a $4 \%$ paraformaldehyde $(0.2 \mathrm{ml})$ was gently injected into the left pulmonary lobes. Angiocath was discharged, trachea was sutured and together with left pulmonary lobes was removed. The lung specimen was fixed in $4 \%$ paraformaldehyde overnight. For paraffin sections, left pulmonary lobe was processed and embedded in paraffin blocks. For frozen sections, the left pulmonary lobe was immersed in graded sucrose and embedded in O.C.T. compound (Tissue-Tek, Tokyo, Japan). Both paraffin $(4 \mu \mathrm{m})$ and frozen $(5 \mu \mathrm{m})$ specimens were cut transversally and attached to Superfrost slide glass (Matsunami, Japan). Paraffin slides were stained with Sirius red and Masson trichrome to evaluate the fibrosis.

For immunohistochemistry, paraffin slides were deparaffinized and rehydrated. The slides were deparaffinized in xylene and rehydrated in graded ethanol and distilled water. A $10 \mathrm{mM}$ citrate buffer ( $\mathrm{pH}$ 6.0) was put in staining dish and preheated in steamer until $95-100{ }^{\circ} \mathrm{C}$. The slides were immersed into preheated citrate buffer for retrieval of antigens for $15 \mathrm{~min}$ in steamer. The staining dish was removed from steamer and left for cooling down in room temperature for $20 \mathrm{~min}$. After cooling in room temperature, the slides were washed with phosphate-buffered saline (PBS), treated with $3 \% \mathrm{H}_{2} \mathrm{O}_{2}$ and blocked with $5 \%$ bovine serum albumin. Subsequently, the slides were incubated with first antibodies at $4{ }^{\circ} \mathrm{C}$ overnight. Secondary antibody was applied at room temperature for $1 \mathrm{~h}$. Bound antibody was developed with 3,3'-diaminobenzidine (DAB) chromogen (Dako, Carpinteria, CA, USA). First antibodies used for this technique were as follows: mouse anti alpha-SMA (1:250; Sigma, Saint Louis, MO, USA) and rabbit anti endothelin-1 (1:10; Peninsula Lab., San Carlos, CA, USA). Secondary antibodies used were anti-mouse and anti-rabbit Envision-HRP labelled polymer (Dako, Carpinteria, CA, USA).
For immunofluorescence, frozen slides were air-dried and washed in distilled water for $10 \mathrm{~min}$. Staining dish filled with $10 \mathrm{mM}$ citrate buffer ( $\mathrm{pH}$ 6.0) was preheated in steamer until $95-100^{\circ} \mathrm{C}$. The slides were incubated in preheated $10 \mathrm{mM}$ citrate buffer for retrieval of antigens for $5 \mathrm{~min}$ in steamer. The staining dish was removed from steamer and left for cooling down in room temperature for $20 \mathrm{~min}$. After $20 \mathrm{~min}$ in room temperature, the slides were washed with $0.05 \%$ TritonX in PBS (PBS-T) and blocked with $5 \%$ bovine serum albumin. First antibody was applied and incubated at $4{ }^{\circ} \mathrm{C}$ overnight. Secondary antibody was applied at room temperature for $1 \mathrm{~h}$. DAPI was applied for detection of cell nuclei. First antibodies used for this technique were as follows: anti alpha-SMA FITC conjugate (1:250; Sigma, Saint Louis, MO, USA), rabbit anti $\mathrm{ET}_{\mathrm{A}}$ receptor (1:10; Santa Cruz, CA, USA), rabbit anti $\mathrm{ET}_{\mathrm{B}}$ receptor (1:10; Santa Cruz, CA, USA), rabbit anti von Willebrand factor (vWF) (1:100; Dako, Carpinteria, CA, USA), rat anti CD206 (1:100; AbDSerotec) and rabbit anti-S100A4 (1:100; Abcam, Cambridge, UK). Secondary antibodies used were AlexaFluor (Invitrogen, Eugene, OR, USA) appropriate with first antibody hosts.

\section{Pulmonary artery medial remodeling assessment}

Medial remodeling was assessed with calculation of medial wall thickness index for muscular artery and arteriole muscularization index for arterioles. Two different sections from each animal were evaluated. For medial wall thickness index, eight to ten small (external diameter (ED) 20-50 $\mu \mathrm{m}$ ) and large (ED 50-100 $\mu \mathrm{m}$ ) muscular pulmonary arteries with each section stained with alpha-SMA immunohistochemistry were captured with Keyence Biozero microscope (Osaka, Japan) and analyzed with Image $\mathrm{J}$ program (NIH, Bethesda, MD, USA). Medial wall thickness index was calculated from wall area divided by wall central perimeter; wall area was a subtraction of vascular area and luminal area whereas central perimeter was an average of vascular perimeter and luminal perimeter (Arfian et al. 2012) (Supplementary Fig. S1). For arteriole muscularization index, intraacinar pulmonary arteries were calculated from whole field of sections double-stained with alpha-SMA (vascular smooth muscle marker) and vWF (endothelium marker) immunofluorescence and categorized as fully muscularized, partially muscularized, and nonmuscularized arterioles (ten Freyhaus et al. 2011). Arteriole muscularization index was determined from the ratio of muscularized arterioles (fully and partially) and 
nonmuscularized arterioles (Ozaki et al. 2001).

Pulmonary artery adventitial remodeling assessment and fibroblast and macrophages calculation

Adventitial remodeling was assessed with measurement of adventitial collagen. Masson trichrome collagen staining (blue color) within the adventitia of small pulmonary arteries (external diameter $<100 \mu \mathrm{m}$ ) from two different sections of each animal were measured with Image $\mathrm{J}$ program (NIH, Bethesda, MD, USA). Percentage of adventitial collagen area and adventitial collagen index (adventitial collagen area normalized with adventitial area percentral adventitial perimeter) were used to express adventitial remodeling (Supplementary Fig. S2). Within adventitial areas from two different sections double-stained with alpha-SMA immunofluorescence, fibroblasts (S100A4-positive cells) and M2 macrophages (CD206-positive cells) were calculated.

Right ventricle $(R V)$ systolic pressure and $R V$ hypertrophy and fibrosis measurement

Mice were condition under general anesthesia by inhalated isoflurane. The right ventricle was accessed from subxiphoid by direct percutaneous insertion of $25 \mathrm{G}$ needle connected to a pressure transducer. Right ventricular systolic pressure was recorded on a Macintosh computer using the Mac Lab system (Bioresearch Center) and measured as previously described (Van Hung et al. 2011). Subsequently, the heart was removed. The RV was separated from the left ventricle (LV) and septum (S) and then weighed. The Fulton index (RV/LV $+\mathrm{S}$ wet weight) was determined as an index of RV hypertrophy. For fibrosis, the heart was processed for paraffin block. Paraffin $(4 \mu \mathrm{m})$ specimens were cut transversally and attached to Superfrost slide glass (Matsunami, Japan). Paraffin slides were stained with Sirius red to evaluate the fibrosis.

\section{Gene expression quantification}

Total RNA was extracted from frozen lung tissue using Trizol reagent (Invitrogen, Eugene, OR, USA). A $0.5 \mu \mathrm{g}$ of total RNA was subjected to reverse transcriptase PCR using ReverTra Ace (Toyobo, Osaka, Japan) resulting in cDNA. The concentration of cDNA was determined by nanodrop spectrophotometer. A $10 \mathrm{ng}$ cDNA was applied to real time PCR using Thunderbird SYBR qPCR Mix (Toyobo, Osaka, Japan) on Applied Biosystems 7,500 Real Time PCR Systems (Applied Biosystems, Foster City, CA, USA). Amplification of specified transcript was verified with melting curve analysis. Gene expression quantification for mouse TGF- $\beta$ and Collagen 1A1 were determined using comparative $2^{-\Delta(\Delta \mathrm{CT})}$ formula with $18 \mathrm{~S}$ for internal control normalization. The primers used in these experiments were: TGF- $\beta$ (forward: 5'-TTCCGCTGCTACTGC AAGTCA-3'; reverse: 5'-GGGTAGCGATCGAGT GTCCA-3'), Collagen 1A1 (forward: 5'-ATGCCGCGA CCTCAAGATG-3'; reverse: 5'-TGAGGCACAGAC GGCTGAGTA-3') and 18S (forward: 5'-GTAACCCGT TGAACCCCATT-3'; reverse: 5'-CCATCCAATCGG TAGTAGCG-3').

\section{Protein quantification}

Protein was extracted from frozen pulmonary lobes. The sample was homogenized in protease inhibitor-contained lysis buffer. Protein samples $(40 \mu \mathrm{g})$ were inserted and separated on $8 \%$ SDS-PAGE. Proteins were transferred to Immobilon PVDF membranes (Millipore, Bedford, MA, USA), blocked with $5 \%$ Tris-buffered saline-Tween 20 mixed with $5 \%$ skim milk for $1 \mathrm{~h}$ in room temperature. The protein-containing membranes were subsequently incubated with first antibody overnight in $4{ }^{\circ} \mathrm{C}$. First antibodies used in this experiment were rabbit anti $\mathrm{ET}_{\mathrm{A}}$ receptor (1:50; Santa Cruz, CA, USA), rabbit anti $\mathrm{ET}_{\mathrm{B}}$ receptor (1:50; Santa Cruz, CA, USA) and rabbit anti GAPDH (1:1000; Sigma). The membranes were washed three times with Tris-buffered saline-Tween20 and incubated with horseradish peroxidase conjugated ECL donkey anti-rabbit ECL (1:3000; GE, Buckinghamshire, UK). Membranes were developed in Luminata Forte Western HRP Substrate (Millipore) using FujiFilm LAS-3000 Mini. Blots were quantified and normalized with GAPDH.

\section{Endothelin-1 measurement}

Peptide was extracted from frozen pulmonary lobes. The tissue sample was minced in frozen condition and dipped in tube containing homogenate buffer ( $4 \%$ acetic acid and protease inhibitors). The tube was homogenized by tissue homogenizer. The homogenized tissue was boiled, cooled in ice and centrifuged at 15,000 rpm at $4{ }^{\circ} \mathrm{C}$ for $30 \mathrm{~min}$. Supernatant was collected, loaded into Sep-Pak C-18 cartridges (Waters, Milford, MA, USA) and eluted with $4 \%$ acetic acid $/ 86 \%$ ethanol solution. The eluate was evaporated, freeze-dried, resuspended in assay buffer and applied on QuantiGlo ET-1 immunoassay (R\&D, Minneapolis, MN, USA). The ET-1 peptide level was normalized with tissue wet weight. 


\section{Statistics analysis}

Data were presented in mean and standard error of mean for each group. For comparing mean among groups, one-way ANOVA tests were used and continued with an LSD post hoc analysis for comparing mean difference between two groups. The difference of mean among groups was statistically significant if $p$-value $<0.05$.

\section{Results}

VEETKO mice had significantly reduced small pulmonary artery medial remodeling and arteriole muscularization index after bleomycin-induced pulmonary fibrosis

Medial wall thickness index in muscular pulmonary arteries was increased in bleomycin-induced pulmonary fibrosis (Figs 1A and 1B). In small muscular pulmonary arteries, VEETKO mice had significantly lower medial wall thickness index than that of Wild type mice. VEETKO mice had also significantly reduced number of muscularized arterioles and lower muscularization index than those of Wild type mice after bleomycin-induced pulmonary fibrosis (Figs 1C, 1D and $1 \mathrm{E})$.

VEETKO mice had significantly reduced adventitial collagen accumulation and adventitial fibroblast and M2 macrophage counts

Adventitial remodeling occurred in bleomycininduced pulmonary fibrosis of both genotypes indicated by increased adventitial collagen accumulation. VEETKO mice had significantly reduced adventitial collagen index and adventitial collagen area as compared to that of Wild type mice (Figs 2A, 2B and 2C). Among cells dwelling in adventitia, fibroblasts and macrophages are recognized to be the main contributors in adventitial fibroproliferation and vascular remodeling (Frid et al. 2006). Only a few adventitial fibroblasts (average of 2-3 cells per vessel) and M2 macrophages (average of
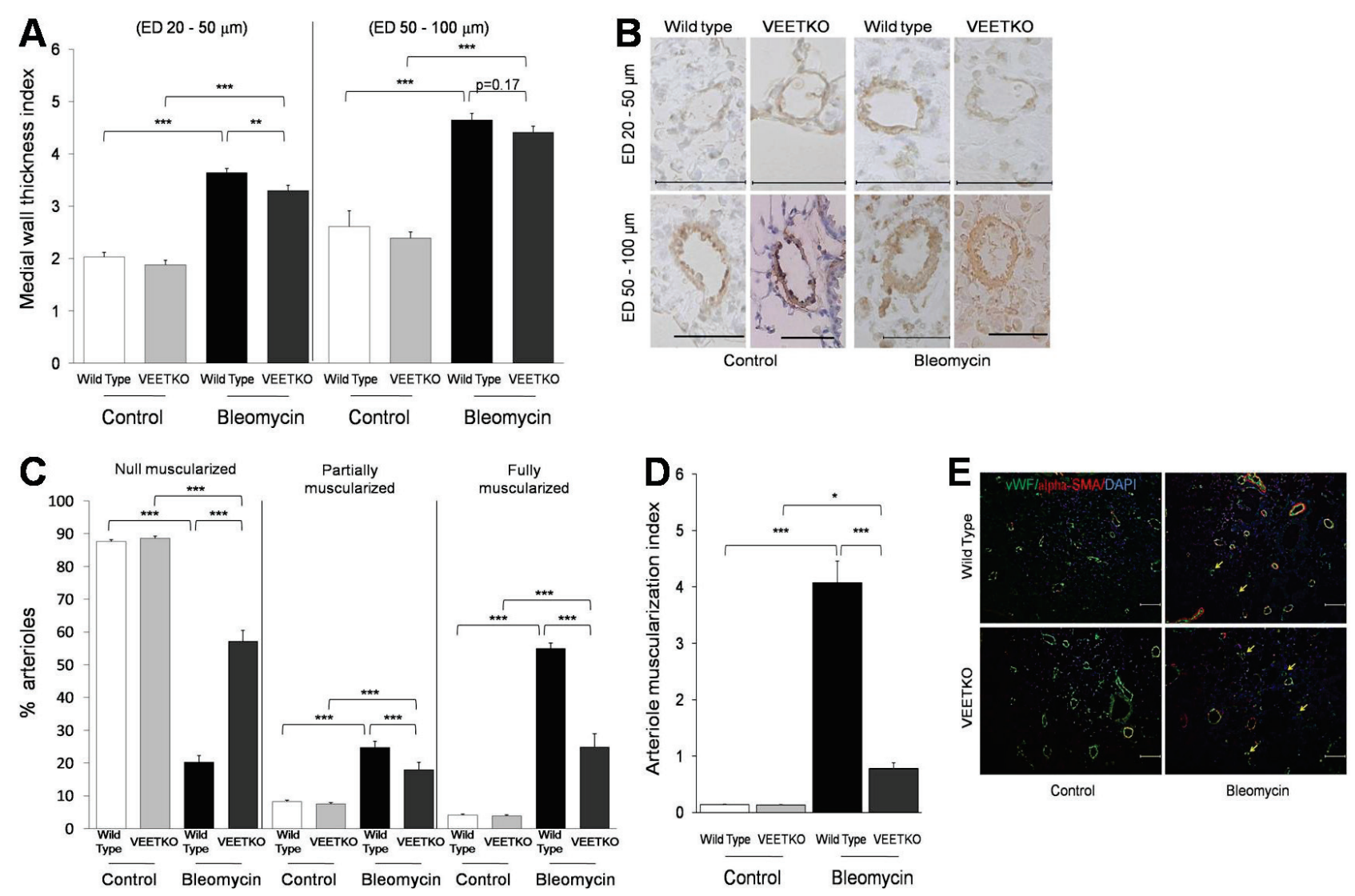

Fig. 1. VEETKO mice had significantly reduced small pulmonary artery medial remodeling and arteriole muscularization index after bleomycin-induced pulmonary fibrosis. (A) Graph represented medial wall thickness index of small muscular pulmonary artery (external diameter (ED) of 20-50 $\mathrm{m}$ ) and large muscular artery (ED of 50-100 $\mu \mathrm{m}$ ) showed significantly lower index of small muscular artery in VEETKO mice after bleomycin-induced pulmonary fibrosis. (B) Representative alpha-SMA immunohistochemistry images of pulmonary artery medial layers (bar $=50 \mu \mathrm{m}$ ). (C) Graph represented the percentage of arteriole muscularization patterns showed significantly less arteriole muscularization in VEETKO mice after bleomycin-induced pulmonary fibrosis. (D) Arteriole muscularization index indicated significantly less remodeled arterioles in VEETKO mice after bleomycin-induced pulmonary fibrosis. (E) Immunofluorescent images of pulmonary artery muscularization determined by double stained of endothelia (vWF) and vascular smooth muscle (alpha-SMA) (bar $=100 \mu \mathrm{m}$, arrow indicated nonmuscularized vessel in bleomycin-induced pulmonary fibrosis). One-way ANOVA: $* \mathrm{p}<0.05, * * \mathrm{p}<0.01$, $* * * p<0.001, n=4$ control mice and 5-7 bleomycin-induced mice each genotype. 
one cell per vessel) were detected in control mice; however, bleomycin instillation stimulated the accumulation of these cells in adventitia (Figs 2D, 2E, 2F and $2 \mathrm{G})$. In bleomycin-induced pulmonary fibrosis, VEETKO mice had significantly lower number of adventitial fibroblasts and M2 macrophages as compared to Wild type mice. Immunofluorescent stain indicated that a number of remodeled arterioles in Wild type mice were in close contact with adventitial fibroblasts and M2 macrophages (Figs 2E and 2G).
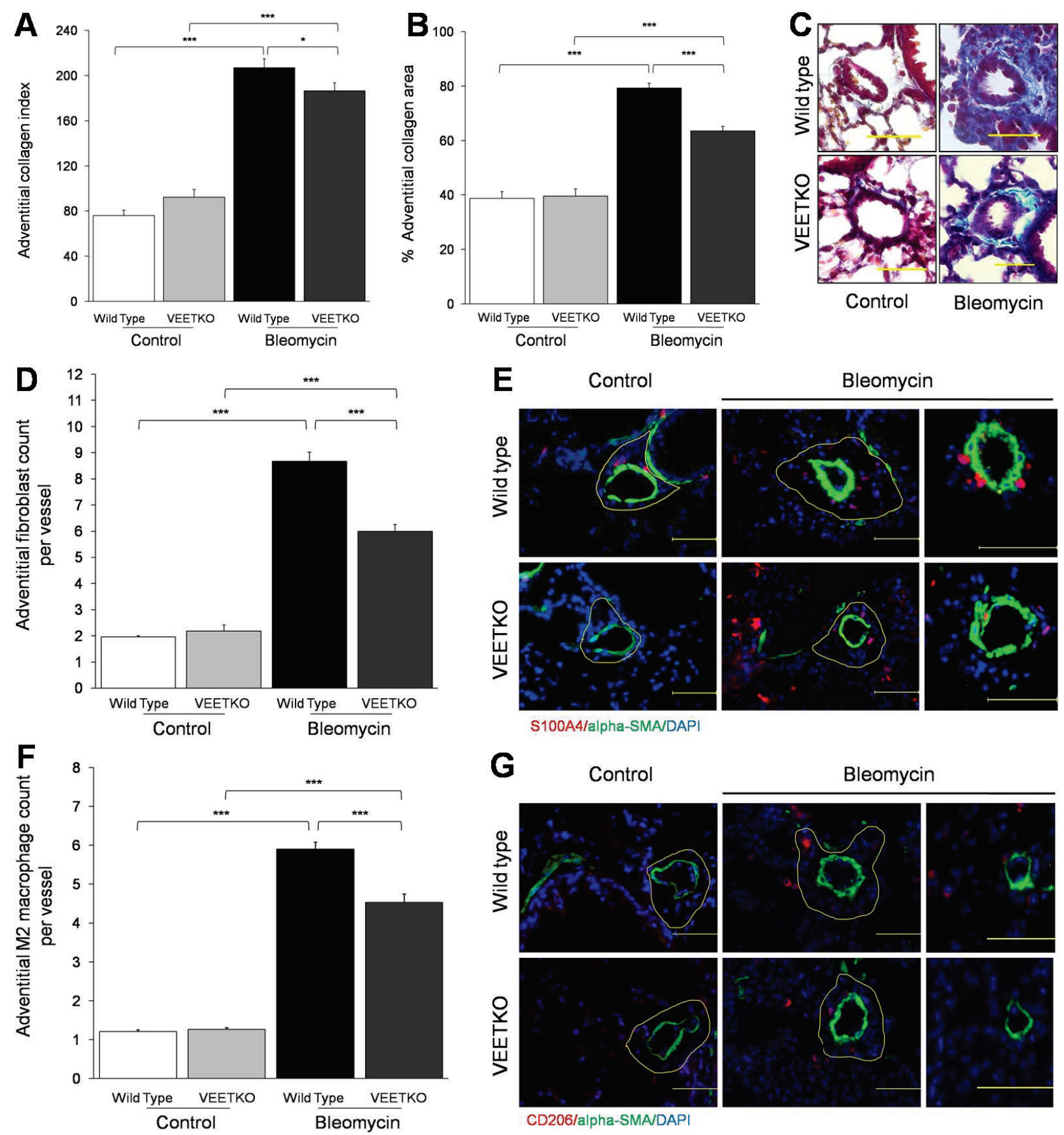

$\mathbf{G}$
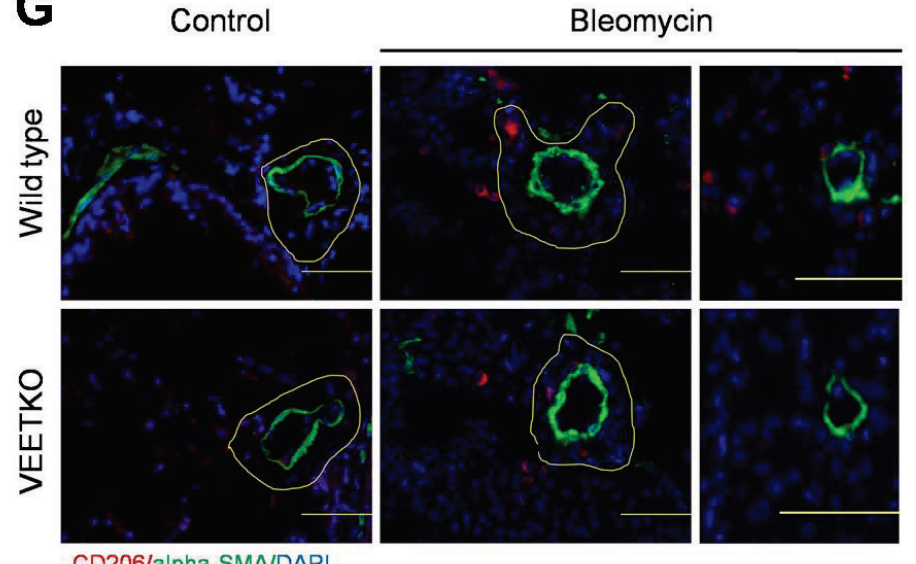

Fig. 2. VEETKO mice had significantly reduced adventitial collagen accumulation and adventitial fibroblast and $M 2$ macrophage counts. (A) Graph represented adventitial collagen index and (B) percentage of collagen area which were significantly lower in VEETKO mice after bleomycin-induced pulmonary fibrosis. (C) Representative image of Masson's trichrome stained adventitia of pulmonary arteries from both genotype (bar=50 $\mu \mathrm{m}$ ). (D) Adventitial fibroblasts and (F) M2 macrophages increased significantly by bleomycin-induced pulmonary fibrosis and VEETKO mice had significantly lower adventitial fibroblast and M2 macrophage count. (E) Representative images of fibroblast (S100A4) double-stained with vascular smooth muscle (alpha-SMA) immunofluorescense (yellow line indicated adventitial border, bar $=50 \mu \mathrm{m}$ ). Adventitial fibroblasts were also situated adjacent to remodeled arterioles (rightmost images). (G) Representative images of M2 macrophages (CD206) double-stained with vascular smooth muscle (alpha-SMA) immunofluorescense (yellow line indicated adventitial border, bar $=50 \mu \mathrm{m}$ ). Adventitial M2 macrophages were also situated adjacent to remodeled arterioles (rightmost images). One-way ANOVA: ${ }^{*} p<0.05, * * p<0.01, * * * p<0.001, n=4$ control mice and 5-7 bleomycin-induced mice each genotype. 

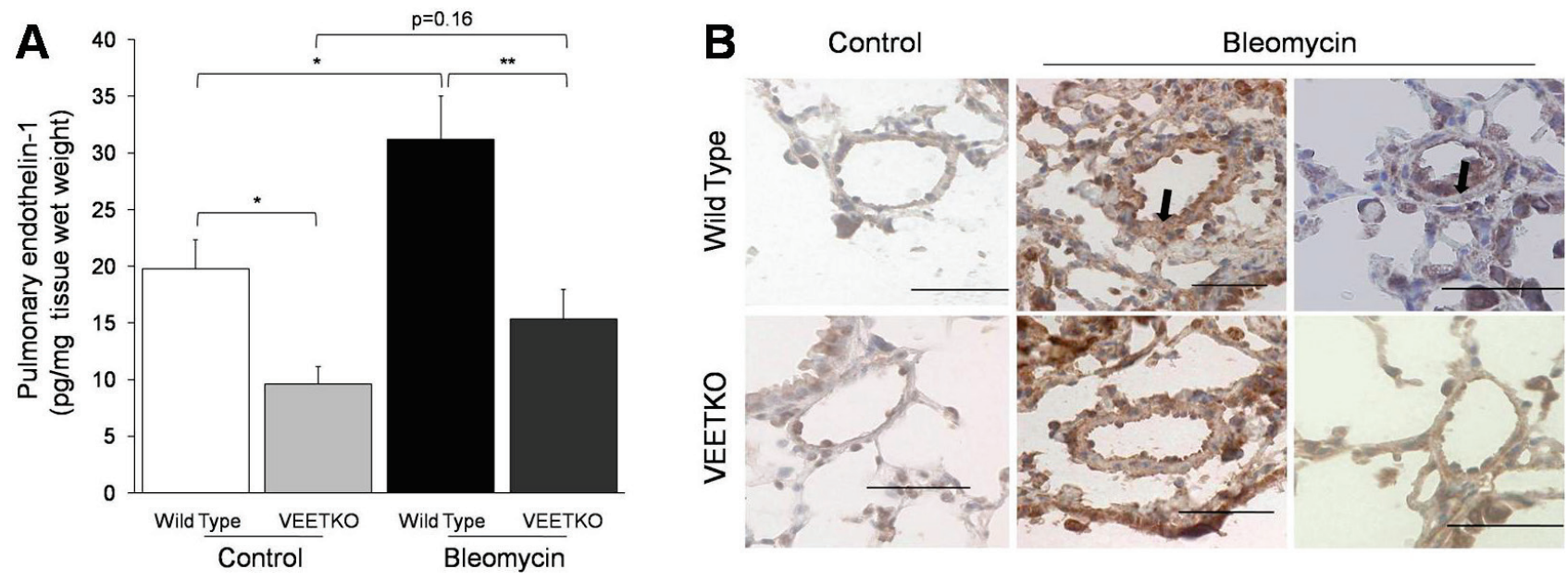

Fig. 3. Endothelin-1 in bleomycin-induced pulmonary fibrosis. VEETKO mice significantly blunted the increase of pulmonary ET-1 levels in bleomycin-induced pulmonary fibrosis. (A) In bleomycin-induced pulmonary fibrosis, pulmonary ET-1 level was significantly reduced in VEETKO mice as compared to Wild type mice ( $31.2 \mathrm{pg} / \mathrm{mg}$ vs. $15.4 \mathrm{pg} / \mathrm{mg}, \mathrm{p}<0.01$, respectively). (B) Representative images of ET-1 immunohistochemistry in pulmonary arteries showed signal in endothelia (arrow) of Wild type mice after bleomycin-induced pulmonary fibrosis $($ bar $=50 \mu \mathrm{m})$. One-way ANOVA: ${ }^{*} \mathrm{p}<0.05,{ }^{*} \mathrm{p}<0.01,{ }^{* * *} \mathrm{p}<0.001, \mathrm{n}=4$ control mice and 5-6 bleomycin-induced mice each genotype.

VEETKO mice significantly blunted the increase of pulmonary ET-1 levels in bleomycin-induced pulmonary fibrosis

Pulmonary ET-1 level was increased after bleomycin-induced pulmonary fibrosis in Wild type mice but not in VEETKO mice (Fig. 3A). In bleomycininduced VEETKO mice, the level of pulmonary ET-1 was significantly lower compared to Wild type mice. Immunohistochemistry of ET-1 showed its increased expression in bleomycin-induced pulmonary fibrosis, mainly in inflammatory cells, epithelial cells as well as endothelial cells (Fig. 3B); however, endothelial cells of VEETKO mice were void of ET-1 immunostaining.

VEETKO mice showed a strong trend in reducing pulmonary collagen content and tendency toward reduced TFG- $\beta$ and collagen $m R N A$

Pulmonary fibrosis was developed in both Wild type and VEETKO mice at 28 days after bleomycin instillation. Collagen staining with both Masson trichrome and Sirius red and collagen content quantification indicated the increased pulmonary collagen in both genotypes (Figs 4A and 4B). VEETKO mice had a strong trend toward reduced pulmonary collagen content (Fig. 4B). Likewise, gene expressions related to fibrosis, i.e. TGF- $\beta$ and collagen, were significantly increased in bleomycin-induced pulmonary fibrosis (Figs 4C and 4D). VEETKO mice had a tendency toward reduced TGF- $\beta$ and collagen mRNA.
VEETKO mice showed no effect on large pulmonary artery medial remodeling, $R V$ peak systolic pressure and $R V$ hypertrophy and fibrosis in bleomycin-induced pulmonary fibrosis

Medial wall thickness index in large muscular pulmonary arteries was increased in bleomycin-induced pulmonary fibrosis in both genotypes of mice (Figs $1 \mathrm{~A}$ and $1 \mathrm{~B})$. VEETKO mice showed no effect on the large muscular pulmonary artery medial wall thickness index. RV systolic pressure was not increased by fibrosis in both genotypes. RV hypertrophy and fibrosis did not develop as well (Figs 5A, 5B and 5C).

VEETKO mice showed no effect on $E T_{A}$ and $E T_{B}$ receptors expression

Bleomycin-induced pulmonary fibrosis significantly increased $\mathrm{ET}_{\mathrm{B}}$ receptor levels in both genotypes, while $\mathrm{ET}_{\mathrm{A}}$ receptors were significantly elevated in VEETKO mice (Figs 6A, 6B, 6C and 6D). In bleomycin-induced pulmonary fibrosis, both Wild type and VEETKO mice had similar expressions of $\mathrm{ET}_{\mathrm{A}}$ and $\mathrm{ET}_{\mathrm{B}}$ receptors. The immunofluorescence showed $\mathrm{ET}_{\mathrm{A}}$ receptors were expressed in vascular and bronchial smooth muscle cells in control and bleomycin-induced mice. In remodeled arterioles of bleomycin-induced mice, we did not observe $\mathrm{ET}_{\mathrm{A}}$ receptors expression (Fig. 6E). The $\mathrm{ET}_{\mathrm{B}}$ receptors were expressed by vascular and bronchial smooth muscle cells as well as endothelial cells (Fig. 6F). In bleomycininduced mice, adventitia of muscular arteries expressed $\mathrm{ET}_{\mathrm{B}}$ receptors especially in Wild type mice. Remodeled arterioles expressed $\mathrm{ET}_{\mathrm{B}}$ receptors in their endothelial cells, but not in smooth muscle cells. 

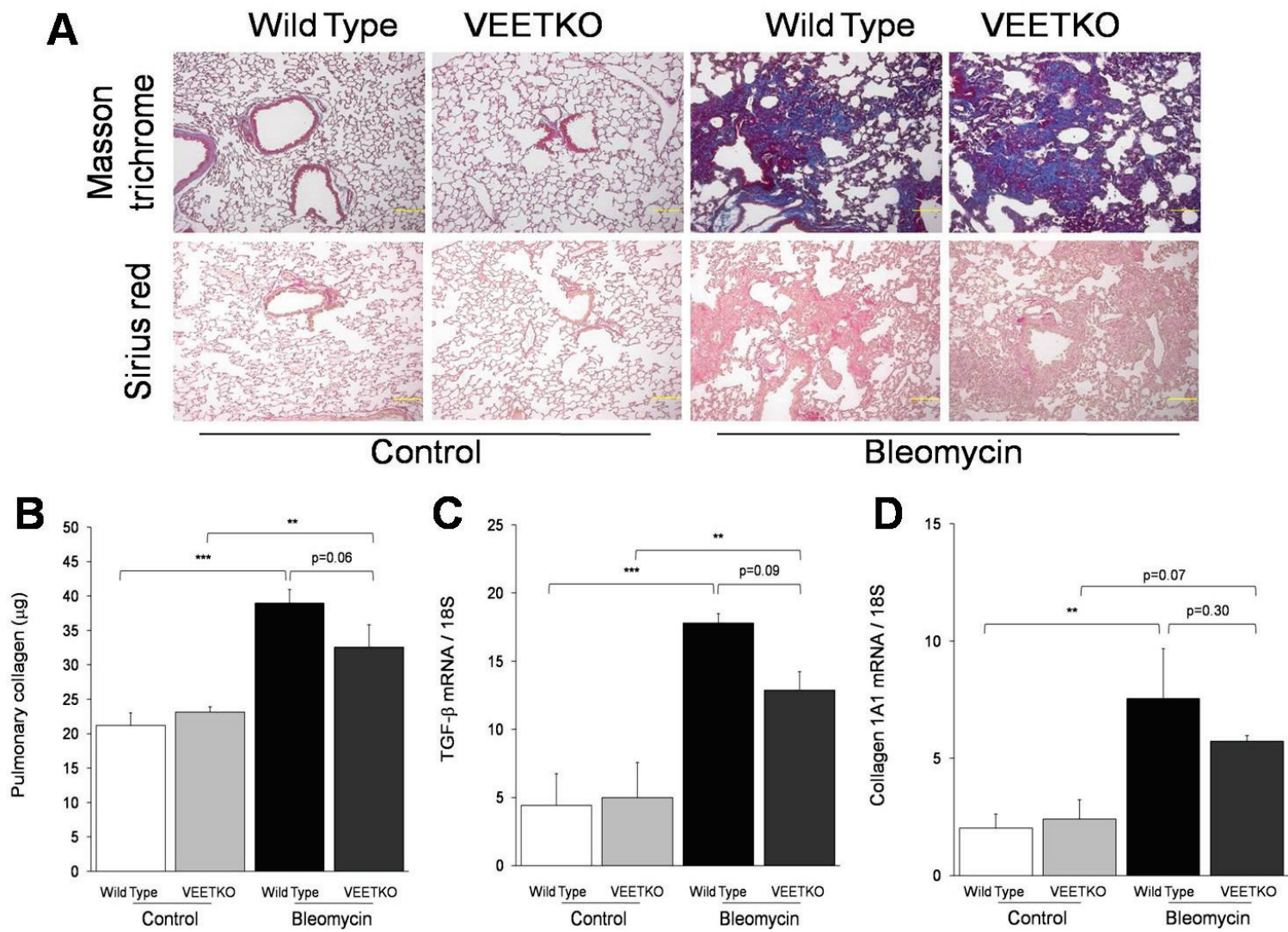

Fig. 4. Bleomycin instillation produced pulmonary fibrosis after 28 days. VEETKO mice showed a strong trend in reducing pulmonary collagen content and tendency toward reduced TFG- $\beta$ and collagen mRNA. (A) Representative Masson's trichrome (upper) and Sirius red (lower) stained images of pulmonary fibrosis induced by bleomycin instillation (bar=100 $\mu \mathrm{m}$ ). The abundant collagen staining was developed in mice in both genotypes after bleomycin instillation. (B) Pulmonary collagen content increased significantly by bleomycin instillation in both genotype mice, there was a trend in reducing pulmonary collagen content in VEETKO mice. (C) TFG- $\beta$ mRNA and (D) collagen 1A1 mRNA levels, normalized with 18S mRNA, were upregulated by bleomycin instillation in both genotype mice, there was a tendency toward reduced TFG- $\beta$ and collagen mRNA in VEETKO mice. One-way ANOVA: $* * p<0.01, * * * p<0.001, n=4$ control and fibrosis mice each genotype.
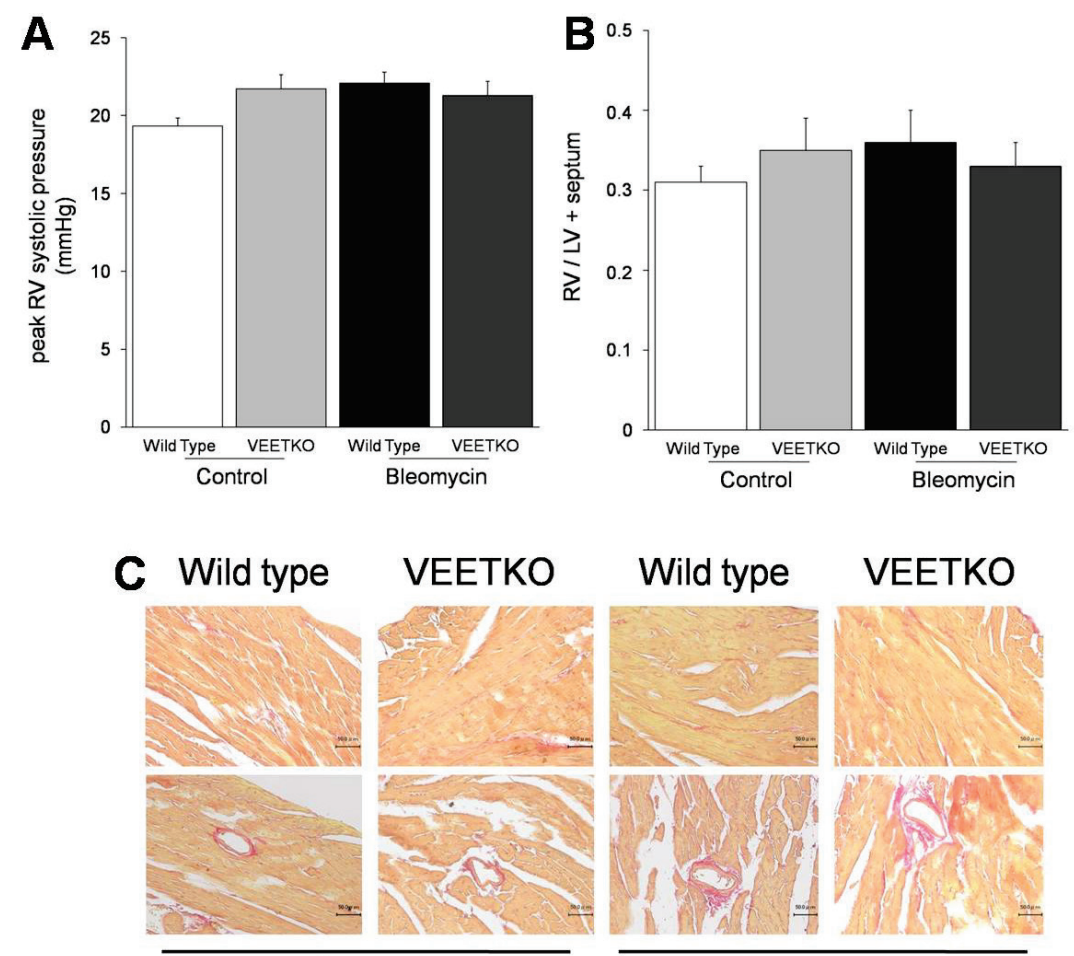

Control

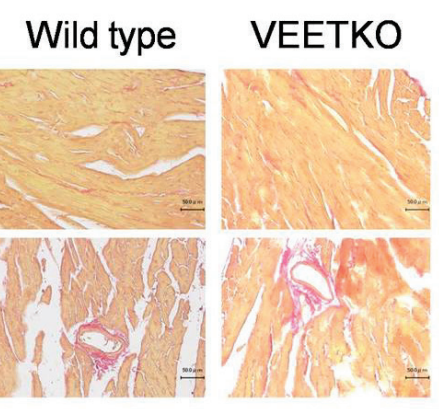

Bleomycin
Fig. 5. Right ventricular (RV) peak systolic pressure, hypertrophy and fibrosis were not affected by bleomycin-induced pulmonary fibrosis in both genotypes. (A) Peak RV systolic pressure $(\mathrm{mm} \mathrm{Hg})$, no statistical significant among groups. (B) RV hypertrophy did not differ among groups. (C) Images of Sirius red stain showing cardiac interstitial (upper) and perivascular (lower) collagen in both genotypes. One-way ANOVA: $* * \mathrm{p}<0.01, * * * \mathrm{p}<0.001, \mathrm{n}=4$ control mice and 5-6 bleomycininduced mice in each genotype. 

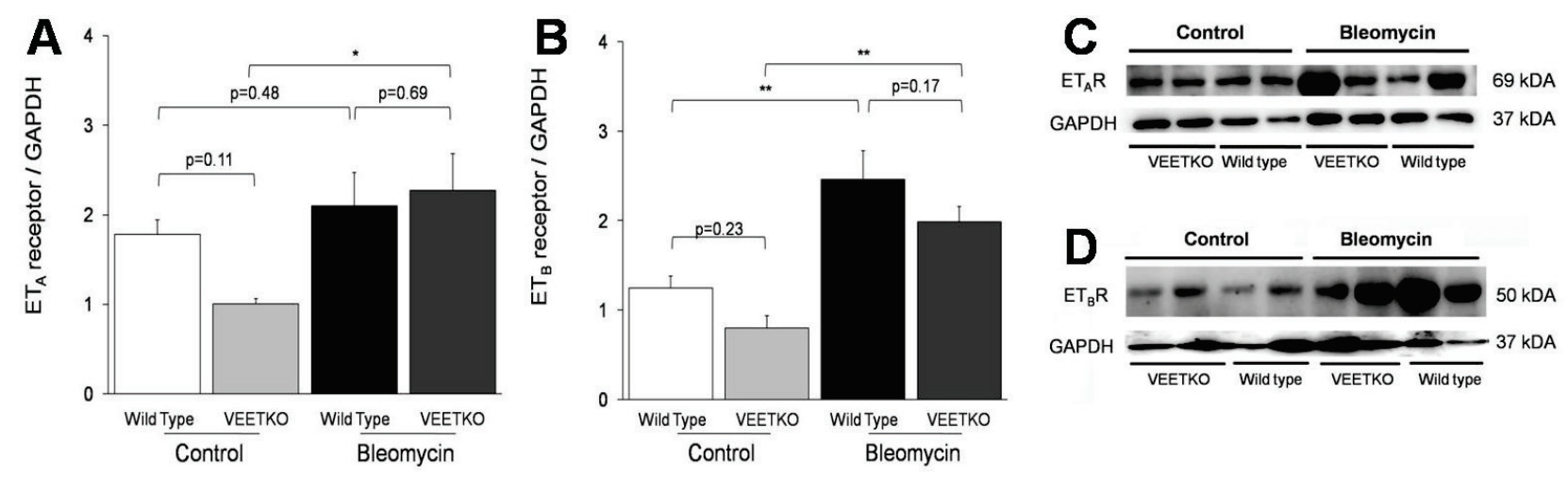

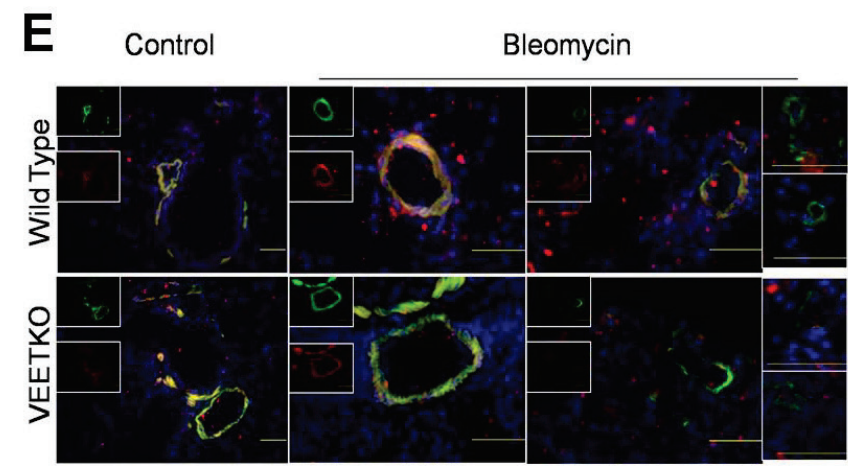

$\mathrm{ET}_{\mathrm{A}}$ receptor/alpha-SMANDAPI

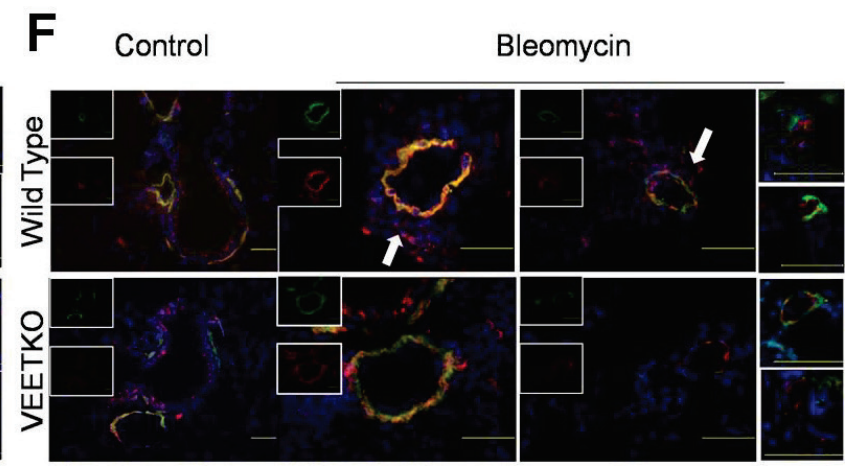

$\mathrm{ET}_{\mathrm{B}}$ receptor/alpha-SMA/DAPI

Fig. 6. $\mathrm{ET}_{\mathrm{A}}$ and $\mathrm{ET}_{\mathrm{B}}$ receptors expression were modified by bleomycin-induced pulmonary fibrosis but VEETKO mice showed no effect on both ET-1 receptor expression. (A) Pulmonary $\mathrm{ET}_{\mathrm{A}}$ receptor level was increased significantly in bleomycin-induced VEETKO mice, whereas not significant in Wild type. However the difference after bleomycin-induced pulmonary fibrosis was not statistically significant. (B) Pulmonary $\mathrm{ET}_{\mathrm{B}}$ receptor level was increased similarly and significantly by bleomycin-induced pulmonary fibrosis in both genotypes. (C) Representative immunoblot of $\mathrm{ET}_{\mathrm{A}}$ receptor $(69 \mathrm{kDA})$ in control and bleomycin-induced mice of both genotypes (normalized with $\mathrm{GAPDH}, 37 \mathrm{kDA}$ ). (D) Representative immunoblot of $\mathrm{ET}_{\mathrm{B}}$ receptor (50 kDA) in control and bleomycin-induced mice of both genotypes (normalized with GAPDH, $37 \mathrm{kDA}$ ). (E) Representative images of $\mathrm{ET}_{\mathrm{A}}$ receptor immunofluorescence of pulmonary arteries showed expression in medial layer of larger vessels, whereas in remodeled arterioles $\mathrm{ET}_{\mathrm{A}}$ fluorescence was undetectable (righmost figures) (bar $=50 \mu \mathrm{m})$. (F) Representative images of $\mathrm{ET}_{\mathrm{B}}$ receptor immunofluorescence in pulmonary arteries showed expression in pulmonary artery endothelia and medial layer. In bleomycin-induced mice, it was also detected in adventitia. In remodeled arterioles, $\mathrm{ET}_{\mathrm{B}}$ receptor was detected only in endothelia (rightmost figures) $(\mathrm{bar}=50 \mu \mathrm{m})$. One-way ANOVA: ${ }^{*} \mathrm{p}<0.05,{ }^{*} \mathrm{p}<0.01, \mathrm{n}=4-5$ mice in each genotype.

\section{Discussion}

Our study indicates endothelial-derived ET-1 promotes pulmonary vascular remodeling secondary to bleomycin-induced pulmonary fibrosis. Abluminal signaling of endothelial-derived ET-1 via $\mathrm{ET}_{\mathrm{A}}$ and $\mathrm{ET}_{\mathrm{B}}$ receptors expressed in medial and adventitial layers amplified medial and adventitial remodeling. Intimal remodeling, which is demonstrated by intimal thickening, was not observed in our models. Medial and adventitial remodeling in our mice models were not sufficient to produce pulmonary hypertension. In fibrotic lung disease, pulmonary vessels undergo various changes related to fibrotic progression (Farkas et al. 2011). Vascular physiological and structural changes in pulmonary fibrosis may be caused mechanically by fibrotic tissue expansion which damages vascular structure (Ebina et al.
2004) or by mediators released during fibrotic development which promote vascular apoptosis (Farkas et al. 2011, Farkas et al. 2009). Apoptotic endothelial cells in fibrotic areas release mediators that stimulate growth of vascular smooth muscle cells and induce arteriole muscularization (Farkas et al. 2009).

Endothelin-1, mainly produced by endothelial cells, is among the mediators increased in fibrosis (Farkas et al. 2011, Park et al. 1997). Our result showed significantly increased lung ET-1 in fibrosis Wild type mice, which was in contrast to VEETKO mice. This fact indicated that in pulmonary fibrosis, endothelial cells were the main source of ET-1, probably from the apoptotic or proliferating endothelial cells (Farkas et al. 2011). Our study also indicated that knock-out of endothelial ET-1 did not prevent the mice from fibrosis induced by bleomycin, despite relatively lower lung ET-1 
levels as compared to Wild type. This finding demonstrated that lung ET-1 is not an essential mediator for pulmonary fibrosis to occur. Although not significantly changed in pulmonary fibrotic development, reduced lung ET-1 in VEETKO mice attenuated vascular remodeling. Increased ET-1 in pulmonary fibrosis contributes to vascular constriction and medial hypertrophy, and when lasting chronically it leads to elevated pulmonary artery pressure and pulmonary hypertension (Galie et al. 2004). ET-1 acts locally through autocrine or paracrine action.

The source of ET-1 acting in pulmonary vascular smooth muscle cells can be divided into two conduits, the first is ET-1 produced by endothelial cells moving outward and reaching medial layers and the second is ET-1 produced by epithelial cells moving inward and contacting medial layers (Farkas et al. 2011). In pulmonary fibrosis, it is not only endothelial cells but also alveolar epithelial cells that are injured (Selman and Pardo 2012). Like endothelial cells, the injured epithelial cells also produce ET-1 (Park et al. 1997). However, it is uncertain whether ET-1 from injured epithelial cells is involved greatly in vascular remodeling, since it must cross the adventitial border before reaching medial layers. Consequently, endothelial-derived ET-1 which is situated adjacent to the medial layer plays a more dominant role in mediating medial remodeling through paracrine action. Reduced medial thickness of muscular pulmonary artery in fibrosis VEETKO mice supports this notion.

Endothelin-1 acts on vascular smooth muscle cells through binding to $\mathrm{ET}_{\mathrm{A}}$ and $\mathrm{ET}_{\mathrm{B}}$ receptors, which subsequently activates phospholipase $\mathrm{C}$ pathways leading to vasoconstriction and cell proliferation (Galie et al. 2004). In pulmonary vessels, both receptors are expressed by vascular smooth muscle cells (Davie et al. 2002). In addition to vascular smooth muscle cells, $\mathrm{ET}_{\mathrm{B}}$ receptors are also expressed by endothelial cells (Davie et al. 2002). Studies suggested the preferential distribution of $\mathrm{ET}_{\mathrm{A}}$ receptors is on the proximal pulmonary artery in rodent lung, whereas $\mathrm{ET}_{\mathrm{B}}$ receptors preponderate in more distal arteries (Soma et al. 1999). This finding indicates that vasoconstriction mediated by $\mathrm{ET}_{\mathrm{A}}$ receptor occurs primarily in proximal arteries, while that of $\mathrm{ET}_{\mathrm{B}}$ receptor takes place in distal pulmonary arteries (Soma et al. 1999). Since distal arteries are associated with resistance vessels which regulate pulmonary vascular tone, $\mathrm{ET}_{\mathrm{B}}$ receptor-mediated vasoconstriction is crucial in maintaining pulmonary vascular tone (Ivy et al. 2001).

Our results showed fibrosis mice had significantly increased $\mathrm{ET}_{\mathrm{B}}$ receptor protein levels, which by using immunofluorescence, we detected $\mathrm{ET}_{\mathrm{B}}$ receptors were expressed by vascular smooth muscle and endothelial cells of remodeled pulmonary arteries. $\mathrm{ET}_{\mathrm{A}}$ receptors were also detected in remodeled vascular smooth muscle cells. The expression of both ET-1 receptors was more obvious in vascular smooth muscle of proximal arteries. In the more distal arteries, the expression of ET-1 receptors became weaker. Furthermore, muscularized arterioles did not express both $\mathrm{ET}_{\mathrm{A}}$ and $\mathrm{ET}_{\mathrm{B}}$ receptors, except for their endothelial cells which expressed $\mathrm{ET}_{\mathrm{B}}$ receptors. These findings were in line with a previous study using hypoxic rodent model (Soma et al. 1999). It suggested that endothelial-derived ET-1 promoted vascular remodeling directly through inside-out pathways via both $\mathrm{ET}_{\mathrm{A}}$ and $\mathrm{ET}_{\mathrm{B}}$ receptors in proximal pulmonary arteries. Current study indicated that highly-selective $\mathrm{ET}_{\mathrm{A}}$ receptors inhibition in bleomycininduced pulmonary fibrosis mice successfully reduced lung injury and attenuated collagen deposition, which may also reduce vascular remodeling (Manitsopoulos et al. 2017). Integrity of $\mathrm{ET}_{\mathrm{B}}$ receptors in endothelial cells is indispensable in regulating pulmonary vascular tone and ET-1 induced vasoconstriction, verified by experiment using mice with endothelial selective knock-out of $\mathrm{ET}_{\mathrm{B}}$ receptors which exhibit more severe vascular remodeling and elevated pulmonary artery pressure in response to hypoxia (Kelland et al. 2010). Endothelial $\mathrm{ET}_{\mathrm{B}}$ receptors, reacting to $\mathrm{ET}-1$, release nitric oxide and prostaglandin $\mathrm{I}_{2}$ which produce vasodilatation (de Nucci et al. 1988). Since we detected $\mathrm{ET}_{\mathrm{B}}$ receptors in endothelial cells of muscularized arterioles, it implicated that muscularized arterioles still have intact capability to dilate vessels and reduce vascular tone. This finding might explain why our Wild type mice model did not develop pulmonary hypertension, despite a significant degree of vascular remodeling and increased ET-1.

In addition to vascular smooth muscle cells, our result showed that $\mathrm{ET}_{\mathrm{B}}$ receptors were also expressed by cells accumulated in adventitial areas of fibrosis mice. Lack of endothelial-derived ET-1 also reduced adventitial remodeling in fibrosis mice. The reduced adventitial collagen content was attributed to less adventitial fibroblasts accumulation. The role of adventitia in promoting medial remodeling has been proposed through outside-in pathways (Stenmark et al. 2006). Inward progression from adventitial to medial layer was mediated by adventitial fibroblast, which is activated by various stimuli (Stenmark et al. 2006). Bleomycin-induced model 
was characterized by abundant accumulation of fibroblast in adventitia. We detected accumulation of fibroblasts in the hilar region, proximal and distal adventitia. Activated adventitial fibroblast release chemokines and adhesion molecules which attract fibrocytes and monocytes from adventitial vasa vasorum, thus promoting recruitment and retention of these cells in adventitia (Stenmark et al. 2006, Li et al. 2011). Adventitial chronic inflammation initiates and perpetuates pulmonary vascular remodeling (Li et al. 2011). Other type of cell, i.e. mast cell, had been implicated in the connection between pulmonary fibrosis and pulmonary hypertension through chymase activity on ET-1 processing and degradation in lung tissue (Kosanovic et al. 2015). Our results showed lack of endothelin-derived ET-1 exhibited reduced adventitial fibroblasts and M2 macrophages, emphasizing its role in recruitment and retention of these cells which promote adventitial and medial remodeling. Furthermore, $\mathrm{ET}_{\mathrm{B}}$ receptors were expressed in adventitia of fibrosis Wild type mice, indicating the ET-1 and $\mathrm{ET}_{\mathrm{B}}$ receptors axis in modulating activation of adventitial fibroblasts. It signified additional mechanisms by which endothelial ET-1 promote medial remodeling, namely through outside-in pathways via recruiting and activating adventitial fibroblasts.

In conclusion, endothelial-derived ET-1 promotes pulmonary vascular remodeling secondary to bleomycininduced pulmonary fibrosis through modulating both inside-out and outside-in models of vascular remodeling.

\section{Conflict of Interest}

There is no conflict of interest.

\section{Acknowledgements}

Authors express gratitude to Klinik Bahasa (Office of Research and Publication, Faculty of Medicine, Public Health and Nursing, Universitas Gadjah Mada) for English language and grammar editing of the manuscript. This study was supported in part by the Japan Society for the Promotion of Science (JSPS) KAKENHI Grant Numbers 26460213 (N.E.).

\section{References}

ARFIAN N, EMOTO N, VIGNON-ZELLWEGER N, NAKAYAMA K, YAGI K, HIRATA K: ET-1 deletion from endothelial cells protects the kidney during the extension phase of ischemia/reperfusion injury. Biochem Biophys Res Commun 425: 443-449, 2012.

BEHR J, RYU JH: Pulmonary hypertension in interstitial lung disease. Eur Respir J 31: 1357-1367, 2008.

DAVIE N, HALEEN SJ, UPTON PD, POLAK JM, YACOUB MH, MORRELL NW, WHARTON J: ET(A) and ET(B) receptors modulate the proliferation of human pulmonary artery smooth muscle cells. Am J Respir Crit Care Med 165: 398-405, 2002.

DE NUCCI G, THOMAS R, D'ORLEANS-JUSTE P, ANTUNES E, WALDER C, WARNER TD, VANE JR: Pressor effects of circulating endothelin are limited by its removal in the pulmonary circulation and by the release of prostacyclin and endothelium-derived relaxing factor. Proc Natl Acad Sci U S A 85: 9797-9800, 1988.

EBINA M, SHIMIZUKAWA M, SHIBATA N, KIMURA Y, SUZUKI T, ENDO M, SASANO H, KONDO T, NUKIWA T: Heterogeneous increase in CD34-positive alveolar capillaries in idiopathic pulmonary fibrosis. Am J Respir Crit Care Med 169: 1203-1208, 2004.

FARKAS L, FARKAS D, ASK K, MOLLER A, GAULDIE J, MARGETTS P, INMAN M, KOLB M: VEGF ameliorates pulmonary hypertension through inhibition of endothelial apoptosis in experimental lung fibrosis in rats. J Clin Invest 119: 1298-1311, 2009.

FARKAS L, GAULDIE J, VOELKEL NF, KOLB M: Pulmonary hypertension and idiopathic pulmonary fibrosis: a tale of angiogenesis, apoptosis, and growth factors. Am J Respir Cell Mol Biol 45: 1-15, 2011.

FRID MG, BRUNETTI JA, BURKE DL, CARPENTER TC, DAVIE NJ, REEVES JT, ROEDERSHEIMER MT, VAN ROOIJEN N, STENMARK KR: Hypoxia-induced pulmonary vascular remodeling requires recruitment of circulating mesenchymal precursors of a monocyte/macrophage lineage. Am J Pathol 168: 659-669, 2006.

GALIE N, MANES A, BRANZI A: The endothelin system in pulmonary arterial hypertension. Cardiovasc Res 61: 227-237, 2004. 
GIAID A, POLAK JM, GAITONDE V, HAMID QA, MOSCOSO G, LEGON S, UWANOGHO D, RONCALLI M, SHINMI O, SAWAMURA T, KIMURA S, YANAGISAWA M, MASAKI T, SPRINGALL DR: Distribution of endothelin-like immunoreactivity and mRNA in the developing and adult human lung. Am J Respir Cell Mol Biol 4: 50-58, 1991.

GIAID A, YANAGISAWA M, LANGLEBEN D, MICHEL RP, LEVY R, SHENNIB H, KIMURA S, MASAKI T, DUGUID WP, STEWART DJ: Expression of endothelin-1 in the lungs of patients with pulmonary hypertension. N Engl J Med 328: 1732-1739, 1993.

GUEMBE L, VILLARO AC: Immunohistochemical mapping of endothelin in the developing and adult mouse lung. J Histochem Cytochem 49: 1301-1309, 2001.

IVY D, MCMURTRY IF, YANAGISAWA M, GARIEPY CE, LE CRAS TD, GEBB SA, MORRIS KG, WISEMAN RC, ABMAN SH: Endothelin B receptor deficiency potentiates ET-1 and hypoxic pulmonary vasoconstriction. Am J Physiol Lung Cell Mol Physiol 280: L1040-L1048, 2001.

KELLAND NF, BAGNALL AJ, MORECROFT I, GULLIVER-SLOAN FH, DEMPSIE Y, NILSEN M, YANAGISAWA M, MACLEAN MR, KOTELEVTSEV YV, WEBB DJ: Endothelial ET(B) limits vascular remodelling and development of pulmonary hypertension during hypoxia. J Vasc Res 47: 16-22, 2010.

KISANUKI YY, EMOTO N, OHUCHI T, WIDYANTORO B, YAGI K, NAKAYAMA K, KEDZIERSKI RM, HAMMER RE, YANAGISAWA H, WILLIAMS SC, RICHARDSON JA, SUZUKI T, YANAGISAWA M: Low blood pressure in endothelial cell-specific endothelin 1 knockout mice. Hypertension 56: 121-128, 2010.

KOMURO I, KURIHARA H, SUGIYAMA T, YOSHIZUMI M, TAKAKU F, YAZAKI Y: Endothelin stimulates c-fos and c-myc expression and proliferation of vascular smooth muscle cells. FEBS Lett 238: 249-252, 1988.

KOSANOVIC D, LUITEL H, DAHAL BK, CORNITESCU T, JANSSEN W, DANSER AH, GARRELDS IM, DE MEY JG, FAZZI G, SCHIFFERS P, IGLARZ M, FISCHLI W, GHOFRANI HA, WEISSMANN N, GRIMMINGER F, SEEGER W, REISS I, SCHERMULY RT: Chymase: a multifunctional player in pulmonary hypertension associated with lung fibrosis. Eur Respir J 46: 1084-1094, 2015.

LI M, RIDDLE SR, FRID MG, EL KASMI KC, MCKINSEY TA, SOKOL RJ, STRASSHEIM D, MEYRICK B, YEAGER ME, FLOCKTON AR, MCKEON BA, LEMON DD, HORN TR, ANWAR A, BARAJAS C, STENMARK KR: Emergence of fibroblasts with a proinflammatory epigenetically altered phenotype in severe hypoxic pulmonary hypertension. J Immunol 187: 2711-2722, 2011.

MANITSOPOULOS N, NIKITOPOULOU I, MANIATIS NA, MAGKOU C, KOTANIDOU A, ORFANOS SE: Highly selective endothelin-1 receptor A inhibition prevents bleomycin-induced pulmonary inflammation and fibrosis in mice. Respiration 95: 122-136, 2018.

MEOLI DF, WHITE RJ: Endothelin-1 induces pulmonary but not aortic smooth muscle cell migration by activating ERK1/2 MAP kinase. Can J Physiol Pharmacol 88: 830-839, 2010.

NATHAN SD, PNOBLE PW, TUDER RM: Idiopathic pulmonary fibrosis and pulmonary hypertension: connecting the dots. Am J Respir Crit Care Med 175: 875-880, 2007.

OZAKI M, KAWASHIMA S, YAMASHITA T, OHASHI Y, RIKITAKE Y, INOUE N, HIRATA KI, HAYASHI Y, ITOH H, YOKOYAMA M: Reduced hypoxic pulmonary vascular remodeling by nitric oxide from the endothelium. Hypertension 37: 322-327, 2011.

PARK SH, SALEH D, GIAID A, MICHEL RP: Increased endothelin-1 in bleomycin-induced pulmonary fibrosis and the effect of an endothelin receptor antagonist. Am J Respir Crit Care Med 156: 600-608, 1997.

RODRIGUEZ-VITA J, RUIZ-ORTEGA M, RUPEREZ M, ESTEBAN V, SANCHEZ-LOPEZ E, PLAZA JJ, EGIDO J: Endothelin-1, via ETA receptor and independently of transforming growth factor-beta, increases the connective tissue growth factor in vascular smooth muscle cells. Circ Res 97: 125-134, 2005.

SELMAN M, PARDO A: Alveolar epithelial cell disintegrity and subsequent activation: a key process in pulmonary fibrosis. Am J Respir Crit Care Med 186: 119-121, 2012.

SHI-WEN X, DENTON CP, DASHWOOD MR, HOLMES AM, BOU-GHARIOS G, PEARSON JD, BLACK CM, ABRAHAM DJ: Fibroblast matrix gene expression and connective tissue remodeling: role of endothelin-1. J Invest Dermatol 116: 417-425, 2001. 
SOMA S, TAKAHASHI H, MURAMATSU M, OKA M, FUKUCHI Y: Localization and distribution of endothelin receptor subtypes in pulmonary vasculature of normal and hypoxia-exposed rats. Am J Respir Cell Mol Biol 20: 620-630, 1999.

STENMARK KR, DAVIE N, FRID M, GERASIMOVSKAYA E, DAS M: Role of the adventitia in pulmonary vascular remodeling. Physiology (Bethesda) 21: 134-145, 2006.

STRIETER RM, MEHRAD B: New mechanisms of pulmonary fibrosis. Chest 136: 1364-1370, 2009.

TEN FREYHAUS H, DAGNELL M, LEUCHS M, VANTLER M, BERGHAUSEN EM, CAGLAYAN E, WEISSMANN N, DAHAL BK, SCHERMULY RT, OSTMAN A, KAPPERT K, ROSENKRANZ S: Hypoxia enhances platelet-derived growth factor signaling in the pulmonary vasculature by down-regulation of protein tyrosine phosphatases. Am J Respir Crit Care Med 183: 1092-1102, 2011.

VAN HUNG T, EMOTO N, VIGNON-ZELlWEGER N, NAKAYAMA K, YAGI K, SUZUKI Y, HIRATA K: Inhibition of vascular endothelial growth factor receptor under hypoxia causes severe, human-like pulmonary arterial hypertension in mice: potential roles of interleukin-6 and endothelin. Life Sci 118: 313-328, 2014. 